Review

\title{
Current Situation of Mycotoxin Contamination and Co-occurrence in Animal Feed-Focus on Europe
}

\author{
Elisabeth Streit ${ }^{1}$, Gerd Schatzmayr ${ }^{1, *}$, Panagiotis Tassis ${ }^{2}$, Eleni Tzika ${ }^{2}$, Daniela Marin ${ }^{3}$, \\ Ionelia Taranu ${ }^{3}$, Cristina Tabuc ${ }^{3}$, Anca Nicolau ${ }^{4}$, Iuliana Aprodu ${ }^{4}$, Olivier Puel ${ }^{5}$ and \\ Isabelle P. Oswald ${ }^{5,6}$
}

1 BIOMIN Research Center, Technopark 1, 3430 Tulln, Austria; E-Mail: elisabeth.streit@biomin.net

2 Faculty of Veterinary Medicine, Aristotle University of Thessaloniki, St Voutyra 11, 54627

Thessaloniki, Greece; E-Mails: tassisp@gmail.com (P.T.); eltzika@vet.auth.gr (E.T.)

3 National Institute for Research and Development in Animal Biology and Nutrition (IBNA), Calea Bucuresti, 077015 Balotesti, Romania; E-Mails: daniela.marin@ibna.ro (D.M.); ionelia.taranu@ibna.ro (I.T.); cristina.tabuc@ibna.ro (C.T.)

4 “Dunarea de Jos" University of Galati, Domneasca 47, 800008 Galati, Romania; E-Mails: anca.nicolau@ugal.ro (A.N.); iuliana.aprodu@ugal.ro (I.A.)

5 Institut National de la Recherche Agronomique (INRA), UMR1331, Toxalim, Research Centre in Food Toxicology, 180 chemin de tournefeuille, F- 31027 Toulouse cedex 3, France;

E-Mails: olivier.puel@toulouse.inra.fr (O.P.); ioswald@toulouse.inra.fr (I.P.O.)

6 Université de Toulouse, INP, UMR1331, Toxalim, F- 31000 Toulouse, France

* Author to whom correspondence should be addressed; E-Mail: gerd.schatzmayr@biomin.net; Tel.: +43-2272-81166-410; Fax: +43-2272-81166-444.

Received: 1 August 2012; in revised form: 13 September 2012 / Accepted: 14 September 2012 / Published: 1 October 2012

\begin{abstract}
Mycotoxins are secondary metabolites produced by fungi especially those belonging to the genus Aspergillus, Penicillum and Fusarium. Mycotoxin contamination can occur in all agricultural commodities in the field and/or during storage, if conditions are favourable to fungal growth. Regarding animal feed, five mycotoxins (aflatoxins, deoxynivalenol, zearalenone, fumonisins and ochratoxin A) are covered by EU legislation (regulation or recommendation). Transgressions of these limits are rarely observed in official monitoring programs. However, low level contamination by Fusarium toxins is very common (e.g., deoxynivalenol $(\mathrm{DON})$ is typically found in more than $50 \%$ of the samples) and co-contamination is frequently observed. Multi-mycotoxin studies reported $75 \%-100 \%$ of the samples to contain more than one mycotoxin which could impact animal
\end{abstract}


health at already low doses. Co-occurrence of mycotoxins is likely to arise for at least three different reasons (i) most fungi are able to simultaneously produce a number of mycotoxins, (ii) commodities can be contaminated by several fungi, and (iii) completed feed is made from various commodities. In the present paper, we reviewed the data published since 2004 concerning the contamination of animal feed with single or combinations of mycotoxins and highlighted the occurrence of these co-contaminations.

Keywords: mycotoxins; feed; co-occurrence; Europe; aflatoxin; deoxynivalenol; zearalenone; fumonisins; ochratoxin A; T-2

\section{Introduction}

The term mycotoxin designates a chemically diverse group of secondary fungal metabolites [1-3], mainly produced by species of the Aspergillus, Penicillium or Fusarium genus [4,5]. Depending on classification, 300-400 mycotoxins are known today [6]. Contamination may occur in the field as well as during (improper) storage and is largely dependent on environmental factors [7,8]. When ingested by humans or animals above a certain concentration, mycotoxins will cause a toxic response referred to as mycotoxicosis $[1,4,5]$. The symptoms elicited by mycotoxin consumption range from reduced animal productivity (reduced body weight gain, reduced fertility) and immune suppression [9], resulting in increased susceptibility to diseases and parasites to overt disease and death. Clinical symptoms of mycotoxin intoxication include diarrhoea, liver and kidney damage, pulmonary oedema, vomiting, haemorrhaging and tumours [1,7]. Under field conditions, mycotoxins usually occur in concentrations leading to reduced animal performance and/or immune suppression without causing any obvious clinical symptoms [5,8]. It is important to emphasise that it is very common for an array of mycotoxins to occur together at low concentrations. This is on the one hand due to the ability of various fungi to simultaneously produce a variety of mycotoxins [10,11] and on the other hand due to the fact that any given commodity is likely to be infected with different types of fungi. Moreover, compound feed is made up of a number of different commodities contributing to the final mycotoxin profile.

In the feed manufacturing process, only a limited number of mycotoxins are subject to regular testing and legal regulations/guidance [12,13], namely aflatoxins (AF), deoxynivalenol (DON), zearalenone (ZEN), fumonisins (FB) and ochratoxin A (OTA). Consequently, this review will focus on these contaminants. In addition, the case of T-2/HT-2 toxin will be addressed. First, a brief introduction about each of the aforementioned toxins including associated adverse effects will be provided. Subsequently, an overview of their occurrence and co-occurrence, with special focus on the EU, will be given. 


\section{Major Mycotoxins}

\subsection{Aflatoxins}

Aflatoxins $\left(B_{1}, B_{2}, G_{1}\right.$ and $\left.G_{2}\right)$ are considered to be the group of mycotoxins of greatest concern from a global perspective [4]. They are primarily produced by Aspergillus flavus, A. parasiticus and in rare cases, by A. nomius [14]. $\mathrm{AFB}_{1}$, the most abundant and most toxic aflatoxin [15], is often referred to as the most potent naturally occurring carcinogen [4]. It is classified as a Group 1 human carcinogen by the International Agency for Research on Cancer (IARC) [16]. Lactating animals fed $\mathrm{AFB}_{1}$ contaminated diets will produce milk contaminated with its monohydroxylated derivative $\mathrm{AFM}_{1}$ [15], classified as $2 \mathrm{~B}$, possibly carcinogenic to humans [16].

Aflatoxin production occurs primarily in regions with tropical or subtropical climates. Hence, from a European perspective, imported feed such as peanut cake, palm kernel, copra and corn gluten meal (depending of origin) is considered to be the most common source of exposure [15]. However, the EFSA report also cites findings from Italy reporting the detection of $\mathrm{AFB}_{1}$ in maize originating from the Po valley after a growth period characterized by high temperatures, drought and strong insect damage. As a result, regional milk samples collected after this particular harvest were found to be contaminated with $\mathrm{AFM}_{1}$ concentration exceeding EU limitations. The incident occurred in 2003 and is discussed in more detail in the section on mycotoxin occurrence in Europe.

The main target organ of aflatoxin toxicity is the liver [15]. Long term exposure of animals to subacutely toxic levels of AFs is associated with liver lesions and/or tumours [17], inferior egg shell and carcass quality, increased disease susceptibility [5], reduced feed efficiency [18], and teratogenicity [1].

\subsection{Deoxynivalenol}

Deoxynivalenol (DON) belongs to the trichothecene group and, albeit being one of its least acutely toxic members, is of particular interest owing to its high prevalence [19]. More precisely DON is classified as type-B trichothecene [20]. It is produced by Fusarium culmorum and $F$. graminearum $[10,19]$. DON contamination is observed worldwide, with cereal crops such as wheat, maize or barley being most frequently affected [20]. Furthermore, silage contamination is regularly observed [21]. Cold and wet weather conditions favour DON production [19] and it was found that the timing of the rainfall is more influential than the amount of precipitation [20,22].

In animal husbandry, DON, also known as vomitoxin, is primarily known for causing feed refusal and emesis in pigs [7]. This mycotoxin also alters the immune response [9,23] and the intestinal functions [24]. DON may be produced together with two acetylated derivatives, 3-AcDON and 15-AcDON, that have differential toxicity on pig intestine [25]. Poultry are not as sensitive to DON [26] and feed refusal is only observed at very high concentrations (16-20 mg/kg feed) [20]. Ruminants are the least sensitive animal species to DON, a fact that is attributed to the capacity of rumen microflora to detoxify this mycotoxin [19]. 


\subsection{T-2 Toxin and HT-2 Toxin}

T-2 and HT-2 toxin are two of the most toxic members of the trichothecene group. They belong to the type A-trichothecenes and are produced by F. sporotrichioides, F. poae and other Fusarium species [27,28]. Oats and oat products were found to be particularly prone to contamination with high levels of T-2 and HT-2 [29] followed by barley [27].

Toxicity data on T-2 and HT-2 are notoriously scarce compared to the other mycotoxins addressed in this review. They were found to impair protein synthesis and exert immunotoxic, haematotoxic and myelotoxic effects [29,30]. Dietary exposure to T-2 and HT-2 was reported to weaken acquired immune response in pigs [31] and cause oral lesions in poultry [32,33]. Feed intake depression and reduced weight gain have been observed in both species [32-34]. Higher T-2/HT-2 concentrations were furthermore found to negatively influence egg production and egg shell thickness in laying hens $[35,36]$. Pigs are most sensitive to T-2/HT-2, followed by poultry. Ruminants are again protected by their microflora and found to be least sensitive to these toxins [29].

A comprehensive review on the occurrence of $\mathrm{T}-2 / \mathrm{HT}-2$ in Europe was provided by van der Fels-Klerx [27]. As a matter of fact, reports on T-2 and HT-2 occurrence are largely restricted to Europe, most often coming from the northern parts of the continent like Scandinavia or the UK $[27,28]$. When guidance values were set for the other major mycotoxins in feed in 2006 by the European Commission data on T-2/HT-2 were deemed too scarce for setting scientifically sound guidance values and further monitoring was recommended [13]. In a recent opinion piece, the EFSA panel on contaminants in the food chain (CONTAM) concluded that based on available data the animal health risk from dietary exposure to T-2/HT-2 was low [29].

\subsection{Zearalenone}

Like DON, zearalenone (ZEN) is produced by fungi of the Fusarium genus. F. culmorum, $F$. graminearum and $F$. heterosporum are among the species found to produce ZEN [10]. Again the risk of contamination is highest in cereal crops [37] but silages, forage, and straw are also likely to contain ZEN [7,21].

Acute toxicity of ZEN is low and adverse effects observed are caused by its ability to interact with the oestrogen receptor [37]. Consequently ZEN is mainly associated with fertility problems and hyper oestrogenic symptoms such as swelling of the vulva and uterus enlargement [1,5,38]. Female swine are most sensitive to ZEN exposure [37] whereas poultry are found to be very tolerant [38]. It is very unlikely that naturally contaminated feedstuff contains ZEN at concentrations sufficiently high to cause adverse effects in poultry. Data on dairy cows is limited but also suggests low responsiveness to ZEN [37].

\subsection{Fumonisins}

Fumonisins are also counted among the Fusarium mycotoxins. In feed crops they are most commonly produced by $F$. proliferatum and $F$. verticillioides. Of the numerous fumonisin analogues known, the $\mathrm{B}$ series $\left(\mathrm{FB}_{1}, \mathrm{FB}_{2}\right.$, and $\left.\mathrm{FB}_{3}\right)$ is most important regarding occurrence and toxicity. $\mathrm{FB}_{1}$ is of greatest concern, as it is the most prevalent and the most toxic of the fumonisins [39]. It has been 
classified as $2 \mathrm{~B}$, possibly carcinogenic to humans [40]. Fumonisin contamination is commonly associated with maize and maize products [39,41]. In a wider context the classification of fumonisins as Fusarium mycotoxins is no longer valid as recently black Aspergilli, most notably A. niger, were also found capable of producing fumonisins [42]. They were reported to cause severe contamination of dried grapes with $\mathrm{FB}_{1-4}$ and other fumonisin isomers [43].

Fumonisin contaminated feed will cause severe diseases like pulmonary oedema in swine and leukoencephalomalacia in horses [44]. Furthermore, fumonisins were found to be immunosuppressive [5,45,46], hepatotoxic, and nephrotoxic [1].

Fumonisins, DON and ZEN are considered to be the most important exponents of the Fusarium mycotoxins with regard to animal health implications [41,47] and associated economic loss [48]. Although fumonisin contamination is not very common in crops other than maize, Fusarium mycotoxins in general are often found to occur together in contaminated cereals [20,41,47]. In most cases, the resulting toxic effects will be additive combinations of the mycotoxins' individual toxicities but synergistic interactions have been observed $[47,49]$.

\subsection{Ochratoxin A}

Ochratoxin A contamination is predominantly associated with insufficient drying or improper storage. It is found all over the world. In temperate regions, OTA contamination is mostly due to Penicillium verrucosum infection while Aspergillus species such as A. carbonarius account for OTA production in warmer regions [50,51]. As for feed ingredients, OTA is most frequently found in cereals but is also known to contaminate soy beans and peanuts. Since fungal growth often occurs at localised hot spots (i.e., an area of elevated water activity) in the stored grain, OTA distribution in contaminated feed lots tends to be very heterogeneous. This fact poses a particular challenge when testing for OTA contamination [50]. Ochratoxin A has been classified as possibly carcinogenic to humans (Group 2B) [52].

The primary target organ for OTA toxicity is the kidney [51]. OTA contamination has been linked to outbreaks of nephropathy in pigs and poultry. It is furthermore associated with immunosuppression, reduced growth rate and increased mortality [50,51]. Owing to their rumen microflora's ability to degrade OTA to the less toxic ochratoxin $\alpha$, ruminants are less sensitive to OTA. However, negative effects on milk production have been described [51]. With regards to OTA residues in animal derived food, specialities made from porcine blood are of most concern. Accumulation in kidney and liver was also observed although at a lesser extent. However, it is estimated that animal derived foodstuff only accounts for $3 \%-10 \%$ (depending on eating habits) of human dietary exposure to OTA in Europe [50].

\section{EU Regulations and Guidance Values}

In the European Union, maximum levels for aflatoxin $\mathrm{B}_{1}$ in feedstuff have been established by the European Parliament [53] and guidance values for DON, ZEN, FB and OTA were issued by the Commission [13]. Selected examples are given in Table 1. Legally binding regulations (as opposed to mere guidance values) have been issued for $\mathrm{AFB}_{1}$ as this mycotoxin is particularly prone to carry-over in milk $\left(\mathrm{AFM}_{1}\right)$. The maximum level is designed to prevent the occurrence of $\mathrm{AFM}_{1}$ at levels considered harmful to human health. 


\section{Occurrence of Mycotoxins in European Feed and Feed Raw Materials}

A number of studies on the occurrence of mycotoxins in European feedstuffs have been published. Examples are given in Table 2. As this review aims at providing an update on mycotoxin contamination in feed, only publications dating from 2004 or later were included in this table. The data clearly show that mycotoxins are ubiquitously present in feed material throughout Europe and that maximum contamination levels exceeding the EU maximum levels or guidance values are likely to occur.

Table 1. Selected examples of maximum levels for aflatoxin $\left(\mathrm{AFB}_{1}\right)$ (European Parliament 2002) and guidance values for deoxynivalenol (DON), zearalenone (ZEN), fumonisins (FB) and ochratoxin A (OTA) (European Commission 2006) in feed.

\begin{tabular}{|c|c|c|}
\hline Mycotoxin & Feedstuff & $\begin{array}{c}\text { Maximum Level or } \\
\text { Guidance Value }^{\text {a }}[\mu \mathrm{g} / \mathrm{kg}]\end{array}$ \\
\hline \multirow[t]{2}{*}{ Aflatoxin $\mathrm{B}_{1}$} & compound feed for dairy animals and young animals & 5 \\
\hline & feed materials & 20 \\
\hline \multirow[t]{3}{*}{ Deoxynivalenol } & complementary and complete feedingstuffs for pigs & 900 \\
\hline & cereals and cereal products & 8,000 \\
\hline & maize by-products & 12,000 \\
\hline \multirow[t]{5}{*}{ Zearalenone } & complementary and complete feedingstuffs for piglets & 100 \\
\hline & and gilts & \\
\hline & complementary and complete feedingstuffs for calves, & 500 \\
\hline & dairy cattle, sheep and goats & \\
\hline & maize by products & 3,000 \\
\hline \multirow{3}{*}{ Fumonisins $\mathrm{B}_{1}+\mathrm{B}_{2}$} & complementary and complete feedingstuffs for pigs, & 5,000 \\
\hline & horses, rabbits and pet animals & \\
\hline & maize and maize products & 60,000 \\
\hline \multirow[t]{2}{*}{ Ochratoxin A } & complementary and complete feedingstuffs for pigs & 50 \\
\hline & cereals and cereal products & 250 \\
\hline
\end{tabular}

${ }^{\mathrm{a}}$ moisture content: $12 \%$.

Miraglia et al. [54] emphasised that occurrence patterns of mycotoxins in Europe are expected to change as a consequence of rising average temperatures. Southern Europe is used as an example to support this statement. The authors report that while the importance of DON is about to decrease, A. flavus infection and aflatoxin contamination, previously uncommon in Europe, will become increasingly important. In fact, in 2003 a hot and dry growing season led to severe A. flavus infection of maize in northern Italy [55]. A survey on 110 samples showed an $\mathrm{AFB}_{1}$ incidence of $75 \%$ with a mean contamination of $4.4 \mu \mathrm{g} / \mathrm{kg}$. Using this maize as feedstuff for dairy cattle led to a widespread $\mathrm{AFM}_{1}$ contamination in milk and several thousand tons of milk exceeding the EU legal limit of $0.05 \mu \mathrm{g} / \mathrm{kg} \mathrm{AFM}_{1}$ [12] had to be discarded. The study by Decastelli et al. [56] presents the results of a surveillance plan spanning the two years following this incident (Table 2). Indicators of this impending change were also found by Goertz et al. [57], who reported $F$. verticillioides, commonly associated with warmer and drier regions such as Italy or Spain, to be the predominant Fusarium species isolated from maize grown in Germany in 2006. As a result, FB contamination was detected in $34 \%$ of the 
samples (Table 2). According to the weather data provided in the report, July and September 2006 had been particularly warm and dry all over Germany.

Table 2. Occurrence of Mycotoxins in European feed and feed raw materials - surveys published since 2004. Mycotoxins other than those discussed in the introduction are listed for the sake of completeness, maximum contamination levels are listed in the "range"-column if no information on the contamination range was provided in the respective publication, exponents next to the mycotoxins' names indicate the analysis method.

\begin{tabular}{|c|c|c|c|c|c|c|}
\hline Country & Commodity & Mycotoxins & $n$ & $\%$ positives & Range $(\mu \mathrm{g} / \mathrm{kg})$ & Reference \\
\hline \multirow{6}{*}{$\begin{array}{l}\text { EU } \\
(\mathrm{CZ}, \mathrm{DK}, \\
\mathrm{ES}, \mathrm{PT}, \\
\mathrm{HU})\end{array}$} & \multirow{6}{*}{$\begin{array}{l}\text { sows feed, } \\
\text { wheat, maize }\end{array}$} & 23 mycotoxins & 82 & 82 & & \multirow{6}{*}{$\begin{array}{l}\text { Monbaliu et al. } \\
{[58]}\end{array}$} \\
\hline & & e.g., $\mathrm{DON}^{\mathrm{z}}$ & 82 & 63 & $74-9,528$ & \\
\hline & & $\mathrm{FB}_{1}$ & 82 & 44 & $36-5,114$ & \\
\hline & & ZEN & 82 & 15 & $58-387$ & \\
\hline & & HT-2 & 82 & 9 & $22-116$ & \\
\hline & & OTA & 82 & 2 & $22-33$ & \\
\hline \multirow[t]{5}{*}{ Europe } & \multirow[t]{5}{*}{ feed materials } & $\mathrm{AF}^{\mathrm{x}, \mathrm{y}}$ & $169^{\mathrm{a}}$ & 15 & $\max : 103$ & \multirow{5}{*}{$\begin{array}{l}\text { Rodrigues and } \\
\text { Naehrer [21] }\end{array}$} \\
\hline & & ZEN & 1517 & 20 & 1,045 & \\
\hline & & DON & 2036 & 58 & 49,000 & \\
\hline & & FB & 114 & 48 & 11,050 & \\
\hline & & OTA & 192 & 35 & 331 & \\
\hline \multirow{6}{*}{$\begin{array}{l}\text { Southern } \\
\text { Europe }\end{array}$} & \multirow[t]{6}{*}{ feed materials } & $\mathrm{AF}^{\mathrm{x}, \mathrm{y}}$ & $127^{\mathrm{a}}$ & 25 & $0.5-66$ & \multirow{6}{*}{$\begin{array}{l}\text { Griessler et al. } \\
\text { [59] }\end{array}$} \\
\hline & & ZEN & 303 & 28 & $10-2,939$ & \\
\hline & & DON & 348 & 66 & $52-4,827$ & \\
\hline & & T-2/HT-2 & 65 & 8 & $35-137$ & \\
\hline & & OTA & 46 & 22 & $1-54$ & \\
\hline & & FB & 89 & 66 & $25-36,390$ & \\
\hline Portugal & $\begin{array}{l}\text { dairy cow's } \\
\text { feed }\end{array}$ & $\mathrm{AF}^{\mathrm{y}}$ & 1001 & 37 & $1-74$ & Martins et al. [60] \\
\hline \multirow[t]{4}{*}{ Portugal } & \multirow{4}{*}{$\begin{array}{l}\text { feed and raw } \\
\text { materials }\end{array}$} & $\mathrm{AF}^{\mathrm{y}}$ & 1936 & 26 & $1-80$ & \multirow[t]{4}{*}{ Martins et al. [61] } \\
\hline & & DON $^{\mathrm{w}}$ & 515 & 6 & $100-1,649$ & \\
\hline & & $\mathrm{FB}^{\mathrm{y}}$ & 545 & 4 & $10-40$ & \\
\hline & & $\mathrm{ZEN}^{\mathrm{w}}$ & 30 & 13 & 104-356 & \\
\hline \multirow[t]{5}{*}{ Portugal } & feed & OTA $^{y}$ & 277 & 8 & $2-6.8$ & \multirow[t]{5}{*}{ Almeida et al. [62] } \\
\hline & fattening pigs & ZEN & 277 & 25 & $5-73$ & \\
\hline & & DON & 277 & 17 & $100-864$ & \\
\hline & \multirow[t]{2}{*}{ sows feed } & ZEN & 127 & 30 & $5-58$ & \\
\hline & & FB & 127 & 9 & $50-391$ & \\
\hline \multirow[t]{2}{*}{ Spain } & feed and raw & OTA $^{y}$ & 91 & 30 & $0.1-12$ & \multirow[t]{2}{*}{ Jaimez et al. [63] } \\
\hline & materials & ZEN & 91 & 8 & $0.5-2$ & \\
\hline
\end{tabular}


Table 2. Cont.

\begin{tabular}{|c|c|c|c|c|c|c|}
\hline Country & Commodity & Mycotoxins & $n$ & $\%$ positives & Range $(\mu \mathrm{g} / \mathrm{kg})$ & Reference \\
\hline \multirow[t]{10}{*}{ Spain } & \multirow[t]{10}{*}{ Barley } & $\mathrm{AF}^{\mathrm{y}}$ & 123 & 100 & max: 0.8 & \multirow{3}{*}{$\begin{array}{l}\text { Ibáñez-Vea et al. } \\
\text { [64] }\end{array}$} \\
\hline & & OTA & 123 & 58 & 4 & \\
\hline & & ZEN & 123 & 39 & 19 & \\
\hline & & DON $^{v}$ & 123 & 95 & 1,111 & \multirow{7}{*}{$\begin{array}{l}\text { Ibáñez-Vea et al. } \\
\text { [65] }\end{array}$} \\
\hline & & NIV & 123 & 20 & 1,435 & \\
\hline & & FUS-X & 123 & 2 & 17 & \\
\hline & & 15-AcDON & 123 & 57 & 65 & \\
\hline & & 3-AcDON & 123 & 28 & 20 & \\
\hline & & DAS & 123 & 25 & 2 & \\
\hline & & T-2/HT-2 & 123 & 24 & 533 & \\
\hline \multirow[t]{2}{*}{ Italy } & \multirow{2}{*}{$\begin{array}{l}\text { feed for dairy } \\
\text { cows }\end{array}$} & \multirow[t]{2}{*}{$\mathrm{AFB}_{1} \mathrm{x}, \mathrm{y}$} & \multirow[t]{2}{*}{616} & 8 (in 2004) & \multirow{2}{*}{ not specified } & \multirow{2}{*}{$\begin{array}{l}\text { Decastelli et al. } \\
{[56]}\end{array}$} \\
\hline & & & & 0 (in 2005) & & \\
\hline \multirow[t]{2}{*}{ Croatia } & \multirow[t]{2}{*}{ maize $^{b}$} & $\mathrm{DON}^{\mathrm{w}, \mathrm{x}, \mathrm{y}}$ & 40 & 85 & $15-17,920$ & \multirow[t]{2}{*}{ Pleadin et al. [66] } \\
\hline & & ZEN & 40 & 88 & $2-5,110$ & \\
\hline \multirow[t]{4}{*}{ Croatia } & \multirow[t]{4}{*}{ maize } & $\mathrm{FB}_{1}{ }^{\mathrm{y}}$ & 49 & 100 & $142-1,378$ & \multirow[t]{4}{*}{ Domijan et al. [67] } \\
\hline & & $\mathrm{FB}_{2}$ & 49 & 6 & $68-3,084$ & \\
\hline & & ZEN & 49 & 84 & $0.4-39$ & \\
\hline & & OTA & 49 & 39 & $0.9-3$ & \\
\hline \multirow[t]{2}{*}{ Greece } & feed and & $\mathrm{AFB}_{1}{ }^{\mathrm{w}}$ & 119 & 0 & & \multirow[t]{2}{*}{ Vlachou et al. [68] } \\
\hline & raw materials & & 183 & 4 & $10-90$ & \\
\hline Czech & grass & $\mathrm{ZEN}^{\mathrm{x}}$ & & & $\max : 173$ & \multirow{4}{*}{$\begin{array}{l}\text { Skládanka et al. } \\
\text { [69] }\end{array}$} \\
\hline \multirow[t]{3}{*}{ Republic } & (field trial) & DON & & & 71 & \\
\hline & & FB & & & nd & \\
\hline & & $\mathrm{AF}$ & & & nd & \\
\hline \multirow[t]{10}{*}{ Slovakia } & \multirow[t]{10}{*}{ poultry feed } & $\mathrm{FB}^{\mathrm{y}}$ & 50 & 98 & $36-1,160$ & \multirow[t]{2}{*}{ Labuda et al. [70] } \\
\hline & & moniliformin & 50 & 52 & $42-1,214$ & \\
\hline & & $\mathrm{ZEN}^{\mathrm{u}, \mathrm{y}, \mathrm{z}}$ & 50 & 88 & $3-86$ & \multirow[t]{8}{*}{ Labuda et al. [71] } \\
\hline & & DON & 50 & 56 & $64-1,230$ & \\
\hline & & $\mathrm{T}-2$ & 50 & 90 & $1-130$ & \\
\hline & & HT-2 & 50 & 76 & $2-173$ & \\
\hline & & 3-AcDON, & & & & \\
\hline & & 15-AcDON, & & & & \\
\hline & & NIV and DAS & & & & \\
\hline & & also analysed & & & & \\
\hline Bulgaria & barley, wheat, & $\mathrm{ZEN}^{\mathrm{y}}$ & 91 & 8 & $\max : 148$ & Manova and \\
\hline & maize & FB & $19^{\mathrm{c}}$ & 95 & $342-4,050$ & Mladenova [72] \\
\hline Romania & Maize, wheat, & AFB1x & 86 & 38 & $\max : 52$ & Tabuc et al. [73] \\
\hline & barley, oat, & OTA & 86 & 14 & 81 & \\
\hline & soya, & DON & 86 & 70 & 2,248 & \\
\hline & sunflower, & ZEN & 86 & 32 & 496 & \\
\hline & colza, rice, & FB & 86 & 41 & 1,008 & \\
\hline & triticale, rye & & 86 & & & \\
\hline & & & 86 & & & \\
\hline
\end{tabular}


Table 2. Cont.

\begin{tabular}{|c|c|c|c|c|c|c|}
\hline Country & Commodity & Mycotoxins & $n$ & \% positives & Range $(\mu \mathrm{g} / \mathrm{kg})$ & Reference \\
\hline \multirow[t]{2}{*}{ Romania } & wheat & DON & 40 & 43 & $19-96$ & Banu et al. [74] \\
\hline & & ZEN & 40 & 10 & $3-6$ & \\
\hline \multirow[t]{8}{*}{ Poland } & cereals, corn, & $\mathrm{AF}^{\mathrm{y}, \mathrm{z}}$ & 1255 & $3-10$ & $0.2-0.9$ & Grajewski et al. \\
\hline & mixed feed, & OTA & 1255 & $36-87$ & $28-760$ & [75] \\
\hline & silages & FB & 1255 & $60-91$ & $435-9,409$ & \\
\hline & & ZEN & 1255 & $60-87$ & $422-1,150$ & \\
\hline & & DON & 1255 & $83-95$ & $3,090-14,470$ & \\
\hline & & NIV, T-2 and & & range of $\%$ & range of yearly & \\
\hline & & HT-2 also & & positives/year & maxima & \\
\hline & & analysed & & & & \\
\hline \multirow[t]{7}{*}{ Germany } & maize & $32^{y}$ & & & $\max :$ & Goertz et al. [57] \\
\hline & (2006 and & e.g. DON (2006) & 44 & 75 & 19,570 & \\
\hline & 2007 harvest) & ZEN (2006) & 44 & 27 & 860 & \\
\hline & & $\mathrm{FB}_{1}(2006)$ & 44 & 34 & 20,690 & \\
\hline & & DON (2007) & 40 & 90 & 16,250 & \\
\hline & & ZEN (2007) & 40 & 93 & 14,580 & \\
\hline & & $\mathrm{FB}_{1}(2007)$ & 40 & 0 & $50(\mathrm{LOQ} / 2)$ & \\
\hline \multirow[t]{8}{*}{ Switzerland } & maize & $\mathrm{DON}^{\mathrm{x}, \mathrm{z}}$ & $19^{d}$ & 100 & $210-8,580$ & Dorn et al. [76] \\
\hline & (field trial) & ZEN & 19 & 79 & $16-1,260$ & \\
\hline & & FB & 19 & 10 & $1,180-2,110$ & \\
\hline & & NIV & 19 & 36 & $80-1,300$ & \\
\hline & growers fields & DON & 12 & 92 & $160-8,570$ & \\
\hline & & ZEN & 12 & 92 & $60-2,240$ & \\
\hline & & FB & 12 & 17 & $300-265,000$ & \\
\hline & & NIV & 12 & 25 & $440-1,530$ & \\
\hline
\end{tabular}

${ }^{a}$ number of samples analysed for each mycotoxin, total number of samples $416 ;{ }^{b}$ sampling after exceptionally cold and wet 2010 growing season; ${ }^{c}$ FBs were determined in maize only; ${ }^{d} 19$ samples in 2006, 2007 samples not shown; ${ }^{\mathrm{u}}$ GC; ${ }^{\mathrm{v}}$ GC-MS; ${ }^{\mathrm{w}}$ TLC; ${ }^{\mathrm{x}}$ ELISA; ${ }^{\mathrm{y}}$ HPLC; ${ }^{\mathrm{z}}$ HPLC-MS/MS; CZ: Czech Republic; DK: Denmark; ES: Spain; PT: Portugal; HU: Hungary; NIV: Nivalenol; FUS-X: Fusarenon-X; DAS: Diacetoxyscirpenol; nd: not detected.

It is however difficult to infer trends or recent developments regarding mycotoxin contamination in European feed from the data presented in Table 2. There are a number of reasons for this, not the least of which is the strong influence of the respective cropping season's climate on the contamination level, causing a high year to year variation of the results, which underlines the importance of implementing regular surveillance programs. Also, applied analysis methods were diverse, including ELISA, TLC, GC and HPLC. Moreover sampling methods are often not described in detail, yet, sampling is considered the largest source of error in mycotoxin analysis [77].

\section{EU and National Monitoring}

The vast majority ( $>98 \%$ ) of mycotoxin related entries concerning feed in the RASFF (Rapid Alert System for Food and Feed) database [78] report the detection of aflatoxins. This is not surprising, as 
aflatoxin $B_{1}$ is to date the only mycotoxin for which legal maximum levels in feedstuff have been established in the European Union. In general, mycotoxins only account for a rather small fraction of the feed related entries in the RASFF database [79], probably for the same reason.

Austrian feed and feed raw materials generally show good compliance with EU regulations and guidance levels. DON is detected most often (around 60\% positives in cereal samples other than maize and $95 \%$ positives in maize samples). ZEN is the second most common mycotoxin, found in about $70 \%$ of unprocessed maize kernel samples. It is rarely detected in other cereal samples. Other mycotoxins such as FB and OTA are detected much less frequently, FB for example is only quantifiable in $10 \%-30 \%$ of each year's maize samples [80-82]. One Austrian maize sample in 2009 and one in 2010 were found to exceed the guidance level for DON $[80,81]$.

The vast majority of the feed samples analysed for mycotoxin contamination in 2010 within the scope of German official controls proved to be compliant with legal requirements. Seven oilseed samples were found to contain $\mathrm{AFB}_{1}$ above the maximum limit. As 1810 samples were tested for $\mathrm{AFB}_{1}$, this makes for only $0.4 \%$ of objectionable samples [83]. Two samples exceeded the guidance value for DON and three samples contained OTA levels above the respective guidance value [84].

Feed official control system in Greece reported a high compliance to EU regulation 1881/2006 in the majority of samples tested in 2010. For the detection of aflatoxin $\mathrm{B}_{1}, 71$ feed and grain samples (wheat, maize, barley etc.) were tested and 5 were non-compliant to EU regulation 32/2002. All samples analysed for OTA, ZEN, and DON were compliant to the respective legislation and no excess levels of T-2 toxin were found either [85].

RIKILT Institute for Food Safety published a report analysing the results from Dutch official controls of feed from 2001-2009 [86]. Mycotoxin concentrations are generally well below the respective maximum level or guidance values although some individual samples exceeded admissible limits. Contamination levels in cereals were generally stable. High DON concentrations were found in liquid pig feed samples, $10 \%$ of which exceeded the guidance value. Oil seeds (sunflower, groundnut) and rice were reported to occasionally contain $\mathrm{AFB}_{1}$ concentrations above the regulatory limit. It was also noted, that soy bean samples with high ZEN content often originated from Argentina.

In Sweden, all feed samples analysed under the national monitoring scheme in 2010 were compliant with EU regulations [87]. In fact, the Swedish board of agriculture did not detect any transgressions of mycotoxin maximum levels or guidance values since 2006 [88-90]. In early 2006, aflatoxin contaminated rice meal used in dairy cattle feed production had been identified as the cause of elevated $\mathrm{AFM}_{1}$ levels in Swedish milk [91].

\section{Mycotoxin Co-occurrence}

Considering the fact that mycotoxigenic fungi are usually capable of producing more than one mycotoxin $[4,10,11]$ and that feed raw materials are commonly infected with various fungal species at a time [10], studying the occurrence of any given mycotoxin alone provides incomplete information about the risk associated with the respective feedstuff. Compound feed is particularly vulnerable to multiple contaminations as it typically contains a mixture of several raw materials [92]. In their meta-analysis, Grenier and Oswald [49] reviewed 112 publications on toxicological interactions of mycotoxins. They found that most of the studies reported synergistic or additive interactions regarding 
adverse effects on animal performance. When it comes to other parameters, especially biochemical ones, results were more variable, ranging from synergistic to antagonistic for the same toxin combination and target variable. Nevertheless the summarised findings underline the importance of studying mycotoxin co-occurrence.

Stoev et al. [93] arrived at a similar conclusion. They analysed a total of 50 feed samples from Bulgarian pig and poultry farms experiencing nephropathy problems. They found that, although all samples were contaminated with OTA at a mean concentration exceeding the EC guidance levels for pig and poultry feed (50 $\mu \mathrm{g} / \mathrm{kg}$ and $100 \mu \mathrm{g} / \mathrm{kg}$ respectively) [13], OTA concentration alone was not high enough to explain the observed symptoms. It was inferred that the nephropathy problems were caused by the combined effects of OTA, $\mathrm{FB}_{1}$ and penicillic acid. Furthermore, a hitherto unknown metabolite found in $92 \%$ of the samples, is suspected as an additional causative agent.

Both publications highlight the necessity of testing for an array of mycotoxins in order to accurately determine feed quality and potential risks. This section is aimed at providing an overview of mycotoxin co-occurrence found in feed and feed raw materials with special focus on European data. The findings mentioned in the following paragraphs are also summarised in Tables 3 and 4. Table 4 contains data on mycotoxin co-occurrence in Europe while Table 3 provides additional information concerning the co-occurrence of AF and FB in maize from South America. Maize is particularly prone to infection by mycotoxigenic fungi, most notably Fusarium sp. [94]. Therefore it is often subject to studies on mycotoxin contamination and co-occurrence.

As for Europe, an UK study screening maize products intended for animal feed for 22 mycotoxins found that all 67 samples were co-contaminated with up to 12 different Fusarium mycotoxins [95]. FBs and DON occurred together in $75 \%$ of the samples and $15-A c D O N$, moniliformin, and ZEN were frequent co-contaminants. None of the samples contained detectable amounts of AF. Prior to this study, Scudamore et al. [96] conducted a survey on 330 samples of feed ingredients and found that maize was by far the most affected by co-contamination. In total, $60 \%$ of the maize samples tested positive for more than one mycotoxin, AF and FB being the most common combination (28\%). Another publication reported the occurrence of 14 different Fusarium mycotoxins in 84 German maize samples sourced after the 2006 and 2007 harvest [57]. Although no information regarding co-occurrence is provided, the high individual incidences of several mycotoxins imply co-occurrence of DON (and its acetylated forms), ZEN, moniliformin, beauvericin, nivalenol, enniatin B, FBs, and/or HT-2 toxin. Likewise, co-occurrence of trichothecenes with ZEN and OTA in 760 Hungarian maize samples can be deduced from the individual toxin prevalences reported by Rafai et al. [97]. This study also comprised 921 samples of other feed raw materials such as wheat, barley, soybean and so on. Typically, DON was found to be the major contaminant, frequently co-occurring with ZEN.

Several groups investigated the occurrence of aflatoxins and fumonisins in Brazilian maize. The results are summarised in Table 3. Joint contamination with these toxins is particularly concerning as there is evidence that $\mathrm{FB}_{1}$ synergistically promotes liver tumours initiated by $\mathrm{AFB}_{1}$ [49]. Brazil is the third most important producer of maize in the world [98]. Hence, contamination levels of Brazilian maize are of international significance. Table 3 also lists a long-term study from Argentina, fourth most important producer of maize worldwide [98]. 
Table 3. Summary of the studies reporting mycotoxin co-occurrence in South American maize.

\begin{tabular}{llcll}
\hline Country & \multicolumn{1}{c}{ Mycotoxins } & $\boldsymbol{n}$ & \multicolumn{1}{c}{ Co-Occurrence } & \multicolumn{1}{c}{ Reference } \\
\hline Brazil & $\mathrm{AFB}_{1}, \mathrm{FB}_{1}, \mathrm{ZEN}$ & 214 & $\mathrm{AFB}_{1}, \mathrm{FB}_{1}: 38 \%$ & Vargas et al. [99] \\
& & & $\mathrm{FB}_{1}, \mathrm{ZEN}: 30 \%$ & \\
& & & $\mathrm{AFB}_{1}, \mathrm{FB}_{1}, \mathrm{ZEN}: 8 \%$ & \\
Brazil & $\mathrm{AFB}_{1}, \mathrm{FB}_{1}$ & 110 & $\mathrm{AFB}_{1}, \mathrm{FB}_{1}: 54.5 \%$ & Carmagos et al. $[100]$ \\
Brazil & $\mathrm{AFs}, \mathrm{FBs}$ & 300 & $\mathrm{AFs}, \mathrm{FBs}: 8 \%$ & Moreno et al. [101] \\
Brazil & $\mathrm{AFs}, \mathrm{FBs}$ & 200 & $\mathrm{AFs}, \mathrm{FBs}: 7 \%$ & Rocha et al. [102] \\
Argentina & $\mathrm{AF}, \mathrm{FB}, \mathrm{ZEN}, \mathrm{DON}$ & 3246 & $\mathrm{AF}, \mathrm{FB}: 8.3 \%$ & Garrido et al. [103] \\
& & & $\mathrm{FB}, \mathrm{ZEN}: 2 \%$ & \\
\hline
\end{tabular}

A survey on feed and feed ingredients $(n=416)$ sourced in Southern Europe from January 2005 to August 2009 established that $22 \%$ of the compound feed samples contained more than one mycotoxin [59]. It was furthermore reported that $23 \%$ of all samples from Spain and $32 \%$ of the Italian samples contained at least two mycotoxins. The samples were tested for AFs, ZEN, B-trichothecenes (DON and AcDON), A-trichothecenes (T-2 toxin and HT-2 toxin), FBs, and OTA. It was stated that Fusarium mycotoxins, namely type B-trichothecenes, ZEN, and FBs, were major contaminants and that their co-occurrence was frequently observed. Almeida et al. [62] analysed 277 samples of feed for fattening pigs marketed in Portugal for OTA, ZEN, and DON. In total, 10\% of the samples were found to contain any two-toxin combination, ZEN and DON co-occurring most often. One sample was contaminated by all three toxins. Moreover, concentrations of FBs and ZEN were determined in 127 samples of sows feed, two of which $(1.5 \%)$ were positive for both analytes. Another study analysing 82 samples of sows feed, wheat and maize sourced in different EU countries in 2008 for the presence of 23 different mycotoxins found that $75 \%$ of the samples contained more than one mycotoxin [58]. The majority of these samples contained DON, AcDON, and FBs in combination with other mycotoxins. Of 50 Slovakian poultry feed samples tested for trichothecenes and ZEN, 84\% contained more than one mycotoxin. A four toxin combination of DON, ZEN, T-2, and HT-2 was detected most frequently (32\%) [71]. A similar study on the occurrence of $\mathrm{FB}_{1}, \mathrm{FB}_{2}$, and moniliformin in poultry feed from Slovakia found that $25(50 \%)$ of the samples contained all three mycotoxins [70]. The description of the samples in both publications strongly suggests, that the samples analysed in both studies were identical. Merging the results shows that all samples were contaminated with at least three mycotoxins and that $82 \%$ contained five or more. The most common combinations being DON, ZEN, T-2, HT-2, $\mathrm{FB}_{1}$, and $\mathrm{FB}_{2}$ and $\mathrm{DON}, \mathrm{ZEN}, \mathrm{T}-2, \mathrm{HT}-2, \mathrm{FB}_{1}, \mathrm{FB}_{2}$, and moniliformin, found in $14 \%$ and $12 \%$ of the samples respectively. Upon investigating the diets of dairy cattle in the Netherlands, Driehuis et al. [104] found that DON and ZEN were co-occurring in $44 \%$ of the diets, silage and compound feed being the major sources of exposure.

Other European studies have focused on a single commodity. For example, Ibáñez-Vea et al. [64] tested 123 Spanish barley samples from the 2007 and 2008 harvest for AFs, ZEN, and OTA. Detectable levels of $\mathrm{AFB}_{1}$ were reported for all the samples and it was found to co-occur with OTA in $31 \%$ of the samples. Co-occurrence of $\mathrm{AFB}_{1}$ and $\mathrm{ZEN}$ was $12 \%$ and $\mathrm{AFB}_{1}, \mathrm{ZEN}$, and OTA co-contamination was detected in $27 \%$ of the samples. The authors published a second study on the occurrence of type A and B trichothecenes in these samples [65]. DON was present in $95 \%$ of them 
and $43 \%$ contained three or more trichothecenes. Combining the results of both studies $96 \%$ of the samples were found to be contaminated with three or more mycotoxins [105]. The combinations $\mathrm{AFB}_{1}$, OTA and DON and $\mathrm{AFB}_{1}$, OTA, DON, and ZEN were most frequent, being observed in $29 \%$ and $26 \%$ of the samples respectively.

Table 4. Overview of studies on mycotoxin co-occurrence in feed and feed ingredients from EU countries.

\begin{tabular}{|c|c|c|c|c|c|}
\hline Country & Commodity & Mycotoxins & $n$ & Co-Occurrence & Reference \\
\hline UK & $\begin{array}{l}\text { Maize } \\
\text { products }\end{array}$ & $\begin{array}{l}22 \text { different } \\
\text { mycotoxins }\end{array}$ & 67 & $\begin{array}{l}100 \% \text { contained } \\
>1 \text { mycotoxin } \\
\text { up to } 12 \text { mycotoxins found to } \\
\text { co-occur }\end{array}$ & Scudamore et al. [95] \\
\hline UK & $\begin{array}{l}\text { feed } \\
\text { ingredients }\end{array}$ & $\begin{array}{l}\text { AFs, FBs, OTA, } \\
\text { ZEN, citrinin, } \\
\text { sterigmatocystein }\end{array}$ & & $\begin{array}{l}14 \%, \text { most often in maize } \\
\text { AF, FB in maize most } \\
\text { common: } 28 \%\end{array}$ & Scudamore et al. [96] \\
\hline Germany & Maize & 32 mycotoxins & 84 & $\begin{array}{l}\text { not specified, implied by high } \\
\text { individual incidences } \\
\text { e.g., DON and ZEN }\end{array}$ & Goertz et al. [57] \\
\hline Hungary & $\begin{array}{l}\text { feed raw } \\
\text { materials }\end{array}$ & $\begin{array}{l}8 \text { Fusarium } \\
\text { mycotoxins }\end{array}$ & 1681 & $\begin{array}{l}\text { not specified, implied by high } \\
\text { individual incidences } \\
\text { e.g., trichothecenes, ZEN and OTA }\end{array}$ & Rafai et al. [97] \\
\hline $\begin{array}{l}\text { Southern } \\
\text { Europe }\end{array}$ & $\begin{array}{l}\text { feed and } \\
\text { feed } \\
\text { ingredients }\end{array}$ & $\begin{array}{l}\text { AFs, ZEN, DON, } \\
\text { AcDON, T-2, } \\
\text { HT-2, FBs, OTA }\end{array}$ & 416 & $\begin{array}{l}22 \% \text { in compound feed } \\
\mathrm{B} \text { trichothecenes, ZEN and FB } \\
\text { co-occurred frequently }\end{array}$ & Griessler et al. [59]. \\
\hline Portugal & $\begin{array}{l}\text { swine feed } \\
\text { (fattening) } \\
\text { sows feed }\end{array}$ & OTA, ZEN, DON & 127 & $\begin{array}{l}10 \% \text { contained any two toxins(most } \\
\text { often ZEN and DON) } \\
\text { OTA, ZEN, DON: } 0.4 \% \\
\text { FB, ZEN: } 1.5 \%\end{array}$ & Almeida et al. [62] \\
\hline $\begin{array}{l}\text { EU }(C Z, \\
\text { DK, ES, } \\
\text { PT, HU) }\end{array}$ & $\begin{array}{l}\text { sows feed, } \\
\text { wheat, } \\
\text { maize }\end{array}$ & 23 mycotoxins & 82 & $75 \%$ co-contaminated & Monbaliu et al. [58] \\
\hline \multirow[t]{2}{*}{ Slovakia } & poultry feed & trichotecenes, ZEN & 50 & $\begin{array}{l}84 \% \text { co-contaminated } \\
\text { DON, ZEN, T-2, HT-2: } 32 \%\end{array}$ & Labuda et al. [71] \\
\hline & & $\begin{array}{l}\text { FB1, FB2, } \\
\text { moniliformin }\end{array}$ & & $50 \%$ contained all three & Labuda et al. [70] \\
\hline Netherlands & $\begin{array}{l}\text { diet of dairy } \\
\text { cattle }\end{array}$ & 20 mycotoxins & 169 & $\begin{array}{l}\text { DON and } \mathrm{ZEN} \text { in } 44 \% \text { of the diets } \\
\text { (major source: silage and } \\
\text { compound feed) }\end{array}$ & Driehuis et al. [104] \\
\hline \multirow[t]{4}{*}{ Spain } & barley & AFs, ZEN, OTA & 123 & $\begin{array}{l}\text { AF, OTA: } 31 \% \\
\text { AF, ZEN: } 12 \% \\
\text { AF, ZEN, OTA: } 27 \%\end{array}$ & Ibáñez-Vea et al. [64] \\
\hline & & $\begin{array}{l}\text { type A and B } \\
\text { trichothecenes }\end{array}$ & & $43 \%$ contained $\geq 3$ trichothecenes & Ibáñez-Vea et al. [65] \\
\hline & & & & AF, OTA, DON: $29 \%$ & Ibáñez-Vea et al. [105] \\
\hline & & combined: & & AF, OTA, DON, ZEN: $26 \%$ & \\
\hline
\end{tabular}


The frequent detection of mycotoxin co-occurrence even in studies screening for a limited number of analytes underlines the importance of multi-mycotoxin analysis methods. Berthiller et al. [6] published a comprehensive review on the evolution of such methods from HPLC-UV to state of the art LC-MS/MS. Of the reports summarised above, Goertz et al. [57], Monbaliu et al. [58] and Driehuis et al. [104] used LC-MS/MS methods for the simultaneous detection of various mycotoxins. A very powerful method to this end was developed by Sulyok et al. who extended their LC-MS/MS method published in 2006 [106] to detect 87 mycotoxins [2]. Upon further development the method was extended by another 19 mycotoxins [107]. Today, it allows for the simultaneous detection of 340 analytes, most of them being mycotoxins (Personal Communication, M. Sulyok).

\section{Conclusions-Future Perspectives}

Mycotoxins are ubiquitously present in European feed and feed raw materials. Although compliance with EU regulations is usually high, continuous monitoring is needed in order to avoid negative impacts on animal health and performance due to elevated contamination levels, which may occur for example after growing seasons characterised by weather conditions particularly favourable to fungal infection and growth. As the timing of the rainfall may be more important than the actual amount of precipitation [20,22], the development of predictive models for mycotoxin occurrence based on regional weather data would be a valuable tool to estimate the risk of contamination after a given growing season. For example, DONcast ${ }^{\circledR}$, a predictive tool for DON in wheat in Ontario (Canada), has been commercialised in 2002 [108]. A European version (DONcast ${ }^{\circledR}$ Europe) is under validation (www.doncast.eu). In Italy, a risk assessment tool predicting FB production by $F$. verticillioides in maize is under development [109]. Although the weather is the most influential parameter regarding the extent of mycotoxin contamination (it was found to explain $48 \%$ of the variation in DON concentration observed in wheat and maize in a Canadian study [110]) other factors are important as well. These are for example the choice of variety, crop rotation (avoiding maize as a pre-crop for wheat), tillage (ploughing reduces inoculum from plant residues), or the planting date (earlier planting of maize is generally preferable). Jouany [94] provided a comprehensive review on this subject. Some studies also investigated whether organically farmed products were more prone to mycotoxin contamination resulting from the absence of pesticide use. Conflicting results have been obtained on this issue, suggesting that other factors may override the effect of chemical control of fungal infection on the prevention of mycotoxin formation [94]. By the same token, there is no indication that organically farmed animal products should be considered any more or less risky in terms of mycotoxin contamination than those produced by conventional farming [111].

It is also necessary to increase the farmer's awareness to the issue of mycotoxins in feed. Piva et al. [55] reported that northern Italian farmers had been warned about elevated $\mathrm{AFB}_{1}$-levels in maize after the 2003 growing season but that the warning was dismissed until the first detection of $\mathrm{AFM}_{1}$ in milk. The occurrence of $\mathrm{AFB}_{1}$ at such high levels in Europe also underlines the fact that climate change will entail a change in the mycotoxin distribution patterns observed today.

With regard to the frequent detection of mycotoxin co-occurrence, even if only a very limited number of mycotoxins are analysed, and the evidence of possible additive or synergistic interaction of co-occurring mycotoxins, guidelines or maximum levels should not only be set for each mycotoxin 
individually but also for particularly concerning combinations which would definitely require more data on the impact of different mycotoxin combinations on different animals species. Possible synergistic interactions with so-called emerging mycotoxins such as moniliformin, beauvericin or enniatins should not be neglected in this respect.

Although a lot of efforts to prevent mycotoxin formation have been undertaken, contaminations of those secondary fungal metabolites still occur. Therefore mycotoxin reduction strategies like the addition of mycotoxin deactivating products based on different strategies (adsorption, biotransformation, biodegradation, bioprotection) should be considered. Also, the development and application of multi-mycotoxin LC-MS/MS methods should be encouraged in order to get a more accurate picture of the extent of multi-mycotoxin contamination. These methods are especially valuable when it comes to detecting masked mycotoxins. Essentially, the term refers to conjugates of mycotoxins that typically go undetected when testing for the parent toxin. These conjugates may be produced by the fungus itself (3-AcDON, 15-AcDON) or formed as a part of the infected plant's defence mechanism (DON-3-Glucoside, ZEN-4-Glucoside) [112]. Apart from exerting toxic effects themselves, there is evidence that some conjugates may be converted into the parent toxin during digestion, further adding to the toxicity of the feed $[113,114]$.

\section{Acknowledgments}

This work was conducted within the scope of the FOODSEG project, funded by the European Union's 7th Framework Program. We also want to thank Richard Öhlinger (AGES) for the information concerning Austria's official feed monitoring scheme and Andrew Robertson for proofreading the manuscript for English language flaws.

\section{Conflict of Interest}

The authors declare no conflict of interest.

\section{References}

1. Binder, E.M. Managing the risk of mycotoxins in modern feed production. Anim. Feed Sci. Technol. 2007, 133, 149-166.

2. Sulyok, M.; Krska, R.; Schuhmacher, R. A liquid chromatography/tandem mass spectrometric multi-mycotoxin method for the quantification of 87 analytes and its application to semi-quantitative screening of moldy food samples. Anal. Bioanal. Chem. 2007, 389, 1505-1523.

3. Fujimoto, H. Yeasts and Molds: Mycotoxins: Classification, Occurrence and Determination. In Encyclopedia of Dairy Sciences, 2nd ed.; Fuquay, J.W., Ed.; Academic Press: San Diego, CA, USA, 2011; pp. 792-800.

4. Sweeney, M.J.; Dobson, A.D.W. Mycotoxin production by Aspergillus, Fusarium and Penicillium species. Int. J. Food Microbiol. 1998, 43, 141-158.

5. Bryden, W.L. Mycotoxins and Animal Production: Insidious Problems Associated with Contaminated Feedstuffs. In Proceedings of the International Symposium on Recent Advances in Animal Nutrition, Kuala Lumpur, Malaysia, 2004. 
6. Berthiller, F.; Sulyok, M.; Krska, R.; Schuhmacher, R. Chromatographic methods for the simultaneous determination of mycotoxins and their conjugates in cereals. Int. J. Food Microbiol. 2007, 119, 33-37.

7. Bryden, W.L. Mycotoxin contamination of the feed supply chain: Implications for animal productivity and feed security. Anim. Feed Sci. Technol. 2012, 173, 134-158.

8. Marquardt, R.R. Effects of molds and their toxins on livestock performance: A western Canadian perspective. Anim. Feed Sci. Technol. 1996, 58, 77-89.

9. Oswald, I.P.; Comara, C. Immunotoxicity of mycotoxins. Rev. Med. Vet. 1998, 149, 585-590.

10. Bottalico, A. Fusarium Diseases of Cereals: Species complex and related mycotoxin profiles in europe. J. Plant Pathol. 1998, 80, 85-103.

11. Atalla, M.M.; Hassanein, N.M.; El-Beih, A.A.; Youssef, Y.A.-G. Mycotoxin production in wheat grains by different Aspergilli in relation to different relative humidities and storage periods. Nahrung 2003, 47, 6-10.

12. The European Commission. Commission Regulation (EU) No 165/2010 of 26 February 2010 amending Regulation (EC) No 1881/2006 setting maximum levels for certain contaminants in foodstuffs as regards aflatoxins. Off. J. Eur. Union 2010, L50/8-L50/12.

13. The European Commission. Commission recommendation of 17 August 2006 on the presence of deoxynivalenol, zearalenone, ochratoxin A, T-2 and HT-2 and fumonisins in products intended for animal feeding. Off. J. Eur. Union 2006, 229, 0007-0009.

14. Ertas, N.; Gonulalan, Z.; Yildirim, Y.; Karadal, F. A survey of concentration of aflatoxin M1 in dairy products marketed in Turkey. Food Control 2011, 22, 1956-1959.

15. Opinion of the Scientific Panel on Contaminants in the Food Chain on a request from the Commission related to Aflatoxin B1 as undesirable substance in animal feed. EFSA J. 2004, 39, 1-27.

16. IARC. Some Naturally Occurring Substances: Food Items and Constituents, Heterocyclic Aromatic Amines and Mycotoxins-Fumonisin B1. IARC Monogr. Eval. Carcinog. Risks Hum. 1993, 56, 245-395.

17. Wogan, G.N. Chemical Nature and Biological Effects of the Aflatoxins. Bacteriol. Rev. 1966, 30, 460-470.

18. D’Mello, J.P.F.; Macdonald, A.M.C. Mycotoxins. Anim. Feed Sci. Technol. 1997, 69, 155-166.

19. Rotter, B.A.; Prelusky, D.B.; Pestka, J.J. Toxicology of deoxynivalenol (vomitoxin). J. Toxicol. Environ. Health 1996, 48, 1-34.

20. Opinion of the Scientific Panel on Contaminants in the Food Chain on a request from the Commission related to Deoxynivalenol (DON) as undesirable substance in animal feed. EFSA J. 2004, 73, 1-42.

21. Rodrigues, I.; Naehrer, K. Prevalence of mycotoxins in feedstuffs and feed surveyed worldwide in 2009 and 2010. Phytopathol. Mediterr. 2012, 51, 175-192.

22. Hooker, D.C.; Schaafsma, A.W.; Tamburic-Ilincic, L. Using weather variables pre- and post-heading to predict deoxynivalenol content in winter wheat. Plant Dis. 2002, 86, 611-619.

23. Pinton, P.; Accensi, F.; Beauchamp, E.; Cossalter, A.M.; Callu, P.; Grosjean, F.; Oswald, I.P. Ingestion of Deoxynivalenol (DON) contaminated feed alters the pig vaccinal immune responses. Toxicol. Lett. 2008, 177, 215-222. 
24. Pinton, P.; Nougayrede, J.P.; del Rio, J.C.; Moreno, C.; Marin, D.; Ferrier, L.; Barcarense, A.P.; Kolf-Clauw, M.; Oswald, I.P. The food contaminant, deoxynivalenol, decreases intestinal barrier function and reduces claudin expression. Toxicol. Appl. Pharmacol. 2009, 237, 41-48.

25. Pinton, P.; Tsybulskyy, D.; Lucioli, J.; Laffitte, J.; Callu, P.; Lyazhri, F.; Grosjean, F.; Bracarense, A.P.; Kolf-Clauw, M.; Oswald, I.P. Toxicity of deoxynivalenol and its acetylated derivatives on the intestine: differential effects on morphology, barrier function, tight junctions proteins and MAPKinases. Toxicol. Sci. 2012, doi:10.1093/toxsci/kfs 239.

26. Eriksen, G.S.; Pettersson, H. Toxicological evaluation of trichothecenes in animal feed. Anim. Feed Sci. Technol. 2004, 114, 205-239.

27. Van der Fels-Klerx, H.J. Occurrence data of trichothecene mycotoxins T-2 toxin and HT-2 toxin in food and feed. Available online: http://www.efsa.europa.eu/de/supporting/pub/66e.htm (accessed on 25 July 2012).

28. Edwards, S.G.; Barrier-Guillot, B.; Clasen, P.-E.; Hietaniemi, V.; Pettersson, H. Emerging issues of HT-2 and T-2 toxins in European cereal production. World Mycotoxin J. 2009, 2, 173-179.

29. Scientific Opinion on the risks for animal and public health related to the presence of T-2 and HT-2 toxin in food and feed. EFSA J. 2011, 9, 1-187.

30. Schuhmacher-Wolz, U.; Heine, K.; Schneider, K. Report on toxicity data on trichothecene mycotoxins HT-2 and T-2 toxins. Available online: http://www.efsa.europa.eu/en/supporting/ pub/65e.htm (accessed on 26 July 2012).

31. Meissonnier, G.M.; Laffitte, J.; Raymond, I.; Benoit, E.; Cossalter, A.M.; Pinton, P.; Bertin, G.; Oswald, I.P.; Galtier, P. Subclinical doses of T-2 toxin impair acquired immune response and liver cytochrome P450 in pigs. Toxicology 2008, 247, 46-54.

32. Chi, M.S.; Mirocha, C.J.; Kurtz, H.J.; Weaver, G.; Bates, F.; Shimoda, W. Subacute Toxicity of T-2 Toxin in Broiler Chicks. Poult. Sci. 1977, 56, 306-313.

33. Wyatt, R.D.; Hamilton, P.B.; Burmeister, H.R. The Effect of T-2 Toxin in Broiler Chickens. Poult. Sci. 1973, 52, 1853-1859.

34. Rafai, P.; Bata, Á.; Ványi, A.; Papp, Z.; Brydl, E.; Jakab, L.; Tuboly, S.; Túry, E. Effects of various levels of T-2 toxin on clinical status, performance and metabolism of growing pigs. Vet. Rec. 1995, 136, 485-489.

35. Chi, M.S.; Mirocha, C.J.; Kurtz, H.J.; Weaver, G.; Bates, F.; Shimoda, W. Effects of T-2 Toxin on Reproductive Performance of Health of Laying Hens. Poult. Sci. 1977, 56, 628-637.

36. Wyatt, R.D.; Doerr, J.A.; Hamilton, P.B.; Burmeister, H.R. Egg Production, Shell Thickness and Other Physiological Parameters of Layin Hens Affected by T-2 Toxin. Appl. Microbiol. 1975, 29, 641-645.

37. Opinion of the Scientific Panel on Contaminants in the Food Chain on a request from the Commission related to Zearalenone as undesirable substance in animal feed. EFSA J. 2004, 89, $1-35$.

38. Müller, H.M. Zearalenon-Ein östrogen wirksames Mycotoxin. Übers. Tierernähr. 1978, 6, 265-300.

39. Opinion of the Scientific Panel on Contaminants in Food Chain on a request from the Commission related to fumonisins as undesirable substances in animal feed. EFSA J. 2005, 235, 1-32. 
40. IARC. Some Traditional Herbal Medicines, Some Mycotoxins, Naphthalene and Styrene. IARC Monogr. Eval. Carcinog. Risks Hum. 2002, 82, 301-366.

41. Placinta, C.M.; D'Mello, J.P.F.; Macdonald, A.M.C. A review of worldwide contamination of cereal grains and animal feed with Fusarium mycotoxins. Anim. Feed Sci. Technol. 1999, 78, 21-37.

42. Frisvad, J.C.; Smedsgaard, J.; Samson, R.A.; Larsen, T.O.; Thrane, U. Fumonisin B2 Production by Aspergillus niger. J. Agric. Food Chem. 2007, 55, 9727-9732.

43. Varga, J.; Kocsubé, S.; Suri, K.; Szigeti, G.; Szekeres, A.; Varga, M.; Tóth, B.; Bartók, T. Fumonisin contamination and fumonisin producing black Aspergilli in dried vine fruits of different origin. Int. J. Food Microbiol. 2010, 143, 143-149.

44. Henry, M.H.; Wyatt, R.D. A review of fumonisin production by fusarium moniliforme and fumonisin toxicosis in animals. J. Appl. Poult. Res. 1993, 2, 188-192.

45. Bouhet, S.; Le Dorze, E.; Pérès, S.Y.; Fairbrother, J.M.; Oswald, I.P. Mycotoxin fumonisin B1 selectively down-regulates the basal IL-8 expression in pig intestine: In vivo and in vitro studies. Food Chem. 2006, 44, 1768-1773.

46. Marin, D.E.; Taranu, I.; Pascale, F.; Lionide, A.; Burlacu, R.; Bailly, J.D.; Oswald, I.P. Sex-related differences in the immune response of weanling piglets exposed to low doses of fumonisin extract. Br. J. Nutr. 2006, 95, 1185-1192.

47. D’Mello, J.P.F.; Placinta, C.M.; Macdonald, A.M.C. Fusarium mycotoxins: a review of global implications for animal health, welfare and productivity. Anim. Feed Sci. Technol. 1999, 80, 183-205.

48. Wu, F. Measuring the economic impacts of Fusarium toxins in animal feeds. Anim. Feed Sci. Technol. 2007, 137, 363-374.

49. Grenier, B.; Oswald, I.P. Mycotoxin co-contamination of food and feed: Meta-analysis of publications describing toxicological interactions. World Mycotoxin J. 2011, 4, 285-313.

50. Opinion of the Scientific Panel on Contaminants in Food Chain on a request from the Commission related to ochratoxin A (OTA) as undesirable substance in animal feed. EFSA J. 2004, 101, 1-36.

51. Duarte, S.C.; Lino, C.M.; Pena, A. Ochratoxin A in feed of food-producing animals: An undesirable mycotoxin with health and performance effects. Vet. Microbiol. 2011, 154, 1-13.

52. Some Naturally Occurring Substances: Food Items and Constituents, Heterocyclic Aromatic Amines and Mycotoxins-Ochratoxin A. IARC Monogr. Eval. Carcinog. Risks Hum. 1993, 56, 489-521.

53. The European Commission. Directive 2002/32/EC of the European Parliament and of the Council of 7 May 2002 on undesirable substances in animal feed. Off. J. Eur. Union 2002, 32, $1-22$

54. Miraglia, M.; Marvin, H.J.P.; Kleter, G.A.; Battilani, P.; Brera, C.; Coni, E.; Cubadda, F.; Croci, L.; De Santis, B.; Dekkers, S.; et al. Climate change and food safety: An emerging issue with special focus on Europe. Food Chem. Toxicol. 2009, 47, 1009-1021.

55. Piva, G.; Battilani, P.; Pietri, A. Emerging issues in southern Europe: Aflatoxins in Italy. In The Mycotoxin Factbook, Food and Feed Topics; Barug, D., Bhatnagar, D., Eds.; Wageningen Academic Publishers: Wageningen, The Netherlands, 2006; pp. 139-153. 
56. Decastelli, L.; Lai, J.; Gramaglia, M.; Monaco, A.; Nachtmann, C.; Oldano, F.; Ruffier, M.; Sezian, A.; Bandirola, C. Aflatoxins occurrence in milk and feed in Northern Italy during 2004-2005. Food Control 2007, 18, 1263-1266.

57. Goertz, A.; Zuehlke, S.; Spiteller, M.; Steiner, U.; Dehne, H.W.; Waalwijk, C.; Vries, I.; Oerke, E.C. Fusarium species and mycotoxin profiles on commercial maize hybrids in Germany. Eur. J. Plant Pathol. 2010, 128, 101-111.

58. Monbaliu, S.; van Poucke, C.; Detavernier, C.L.; Dumoulin, F.d.R.; van De Velde, M.; Schoeters, E.; van Dyck, S.; Averkieva, O.; van Peteghem, C.; de Saeger, S. Occurrence of mycotoxins in feed as analyzed by a multi-mycotoxin LC-MS/MS method. J. Agric. Food Chem. 2010, 58, 66-71.

59. Griessler, K.; Rodrigues, I.; Handl, J.; Hofstetter, U. Occurrence of mycotoxins in Southern Europe. World Mycotoxin J. 2010, 3, 301-309.

60. Martins, H.M.; Mendes Guerra, M.M.; d'Almeida Bernardo, F.M. Occurrence of aflatoxin B1 in dairy cow's feed over 10 years in Portugal (1995-2004). Rev. Iberoam. Micol. 2007, 24, 69-71.

61. Martins, H.M.; Marques, M.; Almeida, I.; Guerra, M.M.; Bernardo, F. Mycotoxins in feedstuffs in Portugal: An overview. Mycotoxin Res. 2008, 24, 19-23.

62. Almeida, I.; Martins, H.M.; Santos, S.; Costa, J.M.; Bernardo, F. Co-occurrence of mycotoxins in swine feed produced in Portugal. Mycotoxin Res. 2011, 27, 177-181.

63. Jaimez, J.; Fente, C.A.; Franco, C.M.; Cepeda, A.; Vázquez, B.I. A survey of the fungal contamination and presence of ochratoxin A and zearalenone on Spanish feed and raw materials. J. Sci. Food Agric. 2004, 84, 832-840.

64. Ibáñez-Vea, M.; González-Peñas, E.; Lizarraga, E.; López de Cerain, A. Co-occurrence of aflatoxins, ochratoxin A and zearalenone in barley from a northern region of Spain. Food Chem. 2012, 132, 35-42.

65. Ibáñez-Vea, M.; Lizarraga, E.; González-Peñas, E.; López de Cerain, A. Co-occurrence of type-A and type-B trichothecenes in barley from a northern region of Spain. Food Control 2012, 25, 81-88.

66. Pleadin, J.; Sokolović, M.; Perši, N.; Zadravec, M.; Jaki, V.; Vulić, A. Contamination of maize with deoxynivalenol and zearalenone in Croatia. Food Control 2012, 28, 94-98.

67. Domijan, A.-M.; Peraica, M.; Jurjević, Ž.; Ivić, D.; Cvjetković, B. Fumonisin B1, fumonisin B2, zearalenone and ochratoxin A contamination of maize in Croatia. Food Addit. Contam. 2005, 22, 677-680.

68. Vlachou, S.; Zoiopoulos, P.E.; Drosinos, E.H. Assessment of some hygienic parameters of animal feeds in Greece. Anim. Feed Sci. Technol. 2004, 117, 331-337.

69. Skládanka, J.; Nedělník, J.; Adam, V.; Doležal, P.; Moravcová, H.; Dohnal, V. Forage as a Primary Source of Mycotoxins in Animal Diets. Int. J. Environ. Res. Public Health 2011, 8, 37-50.

70. Labuda, R.; Parich, A.; Vekiru, E.; Tancinová, D. Incidence of Fumonisins, Moniliformin and Fusarium species in Poultry Feed from Slovakia. Ann. Agric. Environ. Med. 2005, 12, 81-86.

71. Labuda, R.; Parich, A.; Berthiller, F.; Tančinová, D. Incidence of trichothecenes and zearalenone in poultry feed mixtures from Slovakia. Int. J. Food Microbiol. 2005, 105, 19-25.

72. Manova, R.; Mladenova, R. Incidence of zearalenone and fumonisins in Bulgarian cereal production. Food Control 2009, 20, 362-365. 
73. Tabuc, C.; Taranu, I.; Calin, L. Survey of mould and mycotoxin contamination of cereals in South-Eastern Romania in 2008-2010. Arch. Zootech. 2011, 14, 25-38.

74. Banu, I.; Aprodu, I.; Nicolau, A. Occurrence of Fusarium Mycotoxins (Deoxynivalenol and Zearalenone) in Wheat and High Fibre Wheat Bread in Eastern Romania. J. Environ. Prot. Ecol. 2011, 12, 519-525.

75. Grajewski, J.; Błajet-Kosicka, A.; Twarużek, M.; Kosicki, R. Occurrence of mycotoxins in Polish animal feed in years 2006-2009. J. Anim. Physiol. Animal Nutr. 2012.

76. Dorn, B.; Forrer, H.R.; Jenny, E.; Wettstein, F.E.; Bucheli, T.D.; Vogelgsang, S. Fusarium species complex and mycotoxins in grain maize from maize hybrid trials and from grower's fields. J. Appl. Microbiol. 2011, 111, 693-706.

77. Whitaker, T.B. Standardisation of mycotoxin sampling procedures: An urgent necessity. Food Control 2003, 14, 233-237.

78. European Commission. RASFF Portal. Available online: https://webgate.ec.europa.eu/ rasff-window/portal/ (accessed on 08 June 2012).

79. European Commission. Rapid Alert System for Food and Feed-Annual Report 2009. Available online: http://ec.europa.eu/food/food/rapidalert/docs/report2009_en.pdf (accessed on 08 June 2012).

80. AGES. Futtermittelbroschüre 2010. Available online: http://www.ages.at/ages/landwirtschaftlichesachgebiete/futtermittel/publikationen-vortraege/futtermittel-broschuere/ (accessed on 25 June 2012).

81. AGES. Futtermittelbroschüre 2009. Available online: http://www.ages.at/ages/landwirtschaftlichesachgebiete/futtermittel/publikationen-vortraege/futtermittel-broschuere/ (accessed on 25 June 2012).

82. AGES. Futtermittelbroschüre 2008. Available online: http://www.ages.at/ages/landwirtschaftlichesachgebiete/futtermittel/publikationen-vortraege/futtermittel-broschuere/ (accessed on 25 June 2012).

83. BVL Jahresstatistik 2010 über die amtliche Futtermittelüberwachung in der Bundesrepublik Deutschland (Langfassung). Available online: http://www.bmelv.de/SharedDocs/Standardartikel/ Landwirtschaft/Tier/Futtermittel/FuttermittelJahresueberwachung.html?nn=448244 (accessed on 27 June 2012).

84. BVL Jahresstatistik 2010 über die amtliche Futtermittelüberwachung in der Bundesrepublik Deutschland (Kurzfassung). Available online: http://www.bmelv.de/SharedDocs/Standardartikel/ Landwirtschaft/Tier/Futtermittel/FuttermittelJahresueberwachung.html?nn=448244 (accessed on 27 June 2012).

85. HMRDF Hellenic Ministry of Rural development and Food-Annual Report 2010. Available online: http://www.minagric.gr/greek/data/GREEK\%20MANCP\%20report\%202010.pdf (accessed on 26 June 2012).

86. Adamse, P.; van Egmond, H.J.; Driessen, J.J.M.; de Rijk, T.C.; de Jong, J.; de Nijs, M. Trend Analysis of Mycotoxins in Animal Feed; RIKILT-Institute of Food Safety: Wageningen, The Netherlands, 2012; pp 1-52. 
87. Jordbruksverket Jordbruksverkets foderkontroll 2010. Available online: http://www. jordbruksverket.se/rapporterbroschyrerochblanketter.4.595401461210ae2d589800033225.html (accessed on 27 June 2012).

88. Jordbruksverket Jordbruksverkets foderkontroll 2009. Available online: http://www.jordbruksverket.se/rapporterbroschyrerochblanketter.4.595401461210ae2d58980003 3225.html (accessed on 27 June 2012).

89. Jordbruksverket Jordbruksverkets foderkontroll 2008. Available online: http://www.jordbruksverket.se/rapporterbroschyrerochblanketter.4.595401461210ae2d58980003 3225.html (accessed on 27 June 2012).

90. Jordbruksverket Jordbruksverkets foderkontroll 2007. Available online: http://www.jordbruksverket.se/rapporterbroschyrerochblanketter.4.595401461210ae2d58980003 3225.html (accessed on 27 June 2012).

91. Jordbruksverket Jordbruksverkets foderkontroll 2006. Available online: http://www.jordbruksverket.se/rapporterbroschyrerochblanketter.4.595401461210ae2d58980003 3225.html (accessed on 27 June 2012).

92. Binder, E.M.; Tan, L.M.; Chin, L.J.; Handl, J.; Richard, J. Worldwide occurrence of mycotoxins in commodities, feeds and feed ingredients. Anim. Feed Sci. Technol. 2007, 137, 265-282.

93. Stoev, S.D.; Dutton, M.F.; Njobeh, P.B.; Mosonik, J.S.; Steenkamp, P.A. Mycotoxic nephropathy in Bulgarian pigs and chickens: Complex aetiology and similarity to Balkan Endemic Nephropathy. Food Addit. Contam. Part A Chem. Anal. Control Risk Assess. 2010, 27, 72-88.

94. Jouany, J.P. Methods for preventing, decontaminating and minimizing the toxicity of mycotoxins in feeds. Anim. Feed Sci. Technol. 2007, 137, 342-362.

95. Scudamore, K.A.; Nawaz, S.; Hetmanski, M.T. Mycotoxins in ingredients of animal feeding stuffs: II. Determination of mycotoxins in maize and maize products. Food Addit. Contam. 1998, $15,30-55$.

96. Scudamore, K.A.; Hetmanski, M.T.; Chan, H.K.; Collins, S. Occurrence of mycotoxins in raw ingredients used for animal feeding stuffs in the United Kingdom in 1992. Food Addit. Contam. 1997, 14, 157-173.

97. Rafai, P.; Bata, Á.; Jakab, L.; Ványi, A. Evaluation of mycotoxin-contaminated cereals for their use in animal feeds in Hungary. Food Addit. Contam. 2000, 17, 799-808.

98. Food and Agriculture Organization of the United Nations (FAO). 2010 data. Available online: http://faostat.fao.org/site/339/default.aspx (accessed on 22 May 2012).

99. Vargas, E.A.; Preis, R.A.; Castro, L.; Silva, C.M.G. Co-occurrence of aflatoxins B1, B2, G1, G2, zearalenone and fumonisin B1 in Brazilian corn. Food Addit. Contam. 2001, 18, 981-986.

100. Camargos, S.M.; Machinski, M.; Soares, L.M.V. Co-occurrence of fumonisins and aflatoxins in freshly harvested Brazilian maize. Trop. Sci. 2001, 41, 182-184.

101. Moreno, E.C.; Garcia, G.T.; Ono, M.A.; Vizoni, É.; Kawamura, O.; Hirooka, E.Y.; Ono, E.Y.S. Co-occurrence of mycotoxins in corn samples from the Northern region of Paraná State, Brazil. Food Chem. 2009, 116, 220-226. 
102. Rocha, L.O.; Nakai, V.K.; Braghini, R.; Reis, T.A.; Kobashigawa, E.; Corrêa, B. Mycoflora and Co-Occurrence of Fumonisins and Aflatoxins in Freshly Harvested Corn in Different Regions of Brazil. Int. J. Mol. Sci. 2009, 10, 5090-5103.

103. Garrido, C.E.; Hernández Pezzani, C.; Pacin, A. Mycotoxins occurrence in Argentina's maize (Zea mays L.), from 1999 to 2010. Food Control 2012, 25, 660-665.

104. Driehuis, F.; Spanjer, M.C.; Scholten, J.M.; te Giffel, M.C. Occurrence of Mycotoxins in Feedstuffs of Dairy Cows and Estimation of Total Dietary Intakes. J. Dairy Sci. 2008, 91, 4261-4271.

105. Ibáñez-Vea, M.; González-Peñas, E.; Lizarraga, E.; López de Cerain, A. Co-occurrence of mycotoxins in Spanish barley: A statistical overview. Food Control 2012, 28, 295-298.

106. Sulyok, M.; Berthiller, F.; Krska, R.; Schuhmacher, R. Development and validation of a liquid chromatography/tandem mass spectrometric method for the determination of 39 mycotoxins in wheat and maize. Rapid Comm. Mass Spectrom. 2006, 20, 2649-2659.

107. Sulyok, M.; Krska, R.; Schuhmacher, R. Application of an LC-MS/MS based multi-mycotoxin method for the semi-quantitative determination of mycotoxins occurring in different types of food infected by moulds. Food Chem. 2010, 119, 408-416.

108. Hooker, D.C.; Schaafsma, A.W.; Tamburic-Ilincic, L. The DONcast Model: Using Weather Variables Pre- and Post-Heading to Predict Deoxynivalenol Content in Winter Wheat. In Proceedings of National Fusarium Head Blight Forum, Holiday Inn Cincinnati-Airport, Erlanger, KY, USA, 2002.

109. Maiorano, A.; Reyneri, A.; Sacco, D.; Magni, A.; Ramponi, C. A dynamic risk assessment model (FUMAgrain) of fumonisin synthesis by Fusarium verticillioides in maize grain in Italy. Crop Prot. 2009, 28, 243-256.

110. Schaafsma, A.W.; Hooker, D.C. Climatic models to predict occurrence of Fusarium toxins in wheat and maize. Int. J. Food Microbiol. 2007, 119, 116-125.

111. Kouba, M. Quality of organic animal products. Livest. Prod. Sci. 2003, 80, 33-40.

112. Berthiller, F.; Schuhmacher, R.; Adam, G.; Krska, R. Formation, determination and significance of masked and other conjugated mycotoxins. Anal. Bioanal. Chem. 2009, 395, 1243-1252.

113. Garais, M.; Bauer, J.; Thiem, J.; Plank, G.; Grabley, S.; Gedek, B. Cleavage of Zearalenone-Glycoside, a "Masked" Mycotoxin, during Digestion in Swine. J. Vet. Med. 1990, 37, 236-240.

114. Vendl, O.; Berthiller, F.; Crews, C.; Krska, R. Simultaneous determination of deoxynivalenol, zearalenone, and their major masked metabolites in cereal-based food by LC-MS-MS. Anal. Bioanal. Chem. 2009, 395, 1347-1354.

(C) 2012 by the authors; licensee MDPI, Basel, Switzerland. This article is an open access article distributed under the terms and conditions of the Creative Commons Attribution license (http://creativecommons.org/licenses/by/3.0/). 